\title{
糖質米「あゆのひかり」の消化性と構造特性
}

\author{
新井陽一 ${ }^{\S}$, 白幡 登, 深澤純一*, 土田真由子**, 中島義信**, \\ 中浦嘉子***, 堀端哲也***, 井ノ内直良*** \\ 花王株式会社ヒューマンヘルスケア研究センターヘルスケア食品研究所 \\ *花王株式会社生活者コミュニケーションセンター \\ **花王株式会社ヒューマンヘルスケアフード\&ビバレッジ事業グループ
}

*** 福山大学生命工学部生命栄養科学科

\section{Digestive and Structural Characteristics of Sugary Rice, Ayunohikari}

\author{
Youichi Arai ${ }^{\S}$, Noboru Shirahata, Junichi Fukasawa*, Mayuko Tsuchida**, Yoshinobu Nakajima**, \\ Yoshiko Nakaura***, Tetsuya Horibata*** and Naoyoshi Inouchi*** \\ Health Care Food Research Laboratries, Human Health Care Research Center, \\ Kao Corporation, 2-1-3, Bunka, Sumida-ku, Tokyo 131-8501 \\ * Consumer Communication Center, Kao Corporation, 2-1-3, Bunka, Sumida-ku, Tokyo 131-8501 \\ ** Food and Beverage Business Group, Human Health Care, Kao Corporation, \\ 14-10, Nihonbashi Kayabacho 1-chome, Chuo-ku, Tokyo 103-8210 \\ *** Department of Nutrition and Life Science, Faculty of Life Science and Biotechnology, \\ Fukuyama University, 1, Sanzo, Gakuen-cho, Fukuyama, Hiroshima 729-0292
}

\begin{abstract}
The artificial digestibility of cooked rice and the structural properties of the endosperm starches of 11 cleaned rice cultivars bred in Japan were examined in vitro. The artificial digestibility was examined in vitro by analyzing the amount of free glucose after the cooked rice was treated by digestive enzyme. The structural properties of the endosperm starch were estimated by analyzing the contents of the apparent amylose and the Fr.A(DP6-12) of the starch. Digestibility of sugary rice, Ayunohikari, was the lowest of 11 rice cultivars including low-, medium-, high-amylose cultivars. The contents of apparent amylose and the Fr.A(DP6-12) of Ayunohikari endosperm starch were $21.8 \%$ and $34.6 \%$, respectively. The factor of the inhibitive effect of digestion of cooked rice of Ayunohikari could not be well explained by the structural properties of the endosperm starch. Additionally, we found that the shape of cooked rice of Ayunohikari was maintained after digestion test. It was suggested that Ayunohikari had the resistant structure, because the inhibitive effect of digestion disappeared by crushing the rice grains. We also speculated that the resistant structure was related to the endosperm cell wall.
\end{abstract}

(Received Feb. 12, 2010 ; Accepted Jun. 15, 2010)

Keywords : sugary rice, Ayunohikari, digestibility, resistant structure

キーワード : 糖質米，あゆのひかり，消化性，難消化性構造

平成 18 年の国民健康・栄養調査 ${ }^{1)}$ によると, (1) 糖尿病 が強く疑われる人と糖尿病の可能性が否定できない人は合 わせて約 1870 万人，(2)高血圧症有病者と正常高值血圧者 は合わせて約 5490 万人，(3) 脂質異常症が疑われる人は約 1410 万人，(4)メタボリックシンドローム（内臓脂肪症候 群）の状況は，40～74 歳でみると強く疑われる者の比率は 男性 $24.4 \%$, 女性 $12.1 \%$, 予備群と考えられる者の比率は

₹131-8501 東京都墨田区文花 2-1-3

* 131-8501 東京都墨田区文花 2-1-3

** 个103-8210 東京都中央区日本橋茅場町 1-14-10

*** 7 729-0292 広島県福山市学園町 1 番地三蔵

§連絡先 (Corresponding author), arai.youichi@kao.co.jp
男性 $27.1 \%$ ，女性 $8.2 \%$ と報告されている。これらは年々 増加傾向にあり，国民医療費の増加と共に大きな社会問題 となっている。

生活習慣病予防には食生活の改善が基本であることは言 うまでもなく，日本人の主食であり，主要な炭水化物摄取 源である米に着目し，健康機能を探索することは重要と考 える.

近年全国各地の研究機関に打いて, 米胚乳測粉のアミ ロースとアミロペクチンの構成比や分子構造を変化させる 変異体として, 低アミロース米 $(d u l l)^{2)}$, 高アミロース 米3), アミロースエクステンダー $(a e)^{4)}$, 糖質米 $(\text { sugary })^{4)}$ 
などが育成され，これらの肧乳澱粉の構造特性が報告され ている5)6). このうち低アミロース米 $(d u l l)$, 高アミロース 米を含む様々なアミロース含量の米を対象に, 消化性や血 糖值への影響を調べたところ, 高アミロース米は有効であ るとの報告 ${ }^{7)}$ はあるが， 糖質米の消化性や血糖值への影響 については不明である，糖質米は，枝切り酵素であるイソ アミラーゼが欠損していることにより, アミロペクチン合 成時にアミロペクチンのクラスター形成が妨げられ, 結果 として分岐がランダムなフィトグリコーゲンを蓄積す る ${ }^{8)}$.この糖質米には, 原品種の金南風に突然変異誘発剂 処理によって作成されたEM5, EM41, EM273, EM754)や EM5 に酒造用掛米用品種であるふくひびき99)を交配して 育成されたあゆのひかり ${ }^{10)}$ が報告されている，著者らは, (独)農業・食品産業技術総合研究機構の北陸研究センター において育成されたあゆのひかりを用いて, 炊飯米の消化 性試験を中心に健康機能の可能性についていくつかの側面 から検討した。

\section{実 験 方 法}

\section{1. 試 料}

(独) 農業・食品産業技術総合研究機構の北陸研究セン ターで栽培されたあゆのひかりとアミロース含量が異なる 市販流通米 10 品種の合計 11 品種の玄米を用いた。

2. 米胚乳澱粉の見かけのアミロース含量およびアミロ ペクチン側鎖長分布の測定

試料は, 歩留まり約 $90 \%$ に搗精した精白米を用い, 冷ア ルカリ浸漬法 ${ }^{11)} に よ り$ 米胚乳澱粉を調製した. イソアミ ラーゼで枝切りした米胚乳澱粉の中圧ゲルろ過クロマトグ ラフィー（GPC）により得られた溶出曲線より肧乳澱粉の アミロース含量を測定した ${ }^{12) 13)}$ 。アミロペクチン側鎖長分 布は，イソアミラーゼで枝切りした肧乳澱粉を試料とし， パルスドアンペロメトリー検出器を用いた陰イオン交換ク ロマトグラフィー（HPAEC-PAD 法）により測定した ${ }^{14) 15)}$. アミロペクチン側鎖中の短鎖率 (Fr. A 含量) は, グルコー ス重合度（DP） 6 から DP50 までの側鎖ピーク面積におけ るDP6 から DP12 までの側鎖ピーク面積の割合として測 定した。

\section{3. 炊飯米の消化性試験}

消化性試験は難消化性澱粉定量法 ${ }^{16)}$ を改変した以下の 方法で遊離グルコース量を試験した。

歩留まり約 $90 \%$ の精白米試料 $1 \mathrm{~g}$ を遠沈管 $(50 \mathrm{~mL})$ に 秤量し, イオン交換水 $1.5 \mathrm{~mL}$ を加えた. オートクレーブ (SS245, （株）トミー精工）により $120^{\circ} \mathrm{C}$ で 10 分間加圧加熱し た後, 室温にて 1 時間放冷した. $37^{\circ} \mathrm{C}$ に加温した $1.8 \mathrm{mg} /$ $\mathrm{mL}$ の-アミラーゼ溶液 (Bacillus subtilis, 20 units $/ \mathrm{mg}$ 以上, カタログ No: 015-03731, 和光純薬工業(株)) $5 \mathrm{~mL}$ を添加した後に 30 秒間攪拌した. $37^{\circ} \mathrm{C}$ に加温した $5 \mathrm{mg} /$ $\mathrm{mL}$ のペプシン（porcine gastric mucosa, 2500-3500 units/ mg protein, P-7012, Sigma）を $1 \mathrm{~mL}$ 添加後, $2 \mathrm{M}$ 塩酸を 加えて pH 1.5 に調整し, 恒温振とう機（TRS-20, (株)井 内盛栄堂) を用いて $37^{\circ} \mathrm{C}, 60 \mathrm{rpm}$ の振とう速度で 30 分間 振とうした。 その後 $0.5 \mathrm{M}$ 䣷酸緩衝液（pH5.0）を $10 \mathrm{~mL}$, $1 \mathrm{M}$ 水酸化ナトリウムを $1 \mathrm{~mL}, 0.06 \mathrm{M}$ 塩化マンガンを 125 $\mu \mathrm{L}, 0.3 \mathrm{M}$ 塩化カルシウムを $125 \mu \mathrm{L}, 4 \mathrm{mg} / \mathrm{mL}$ パンクレア チン溶液 (porcine pancreas, P-1750, Sigma) $125 \mu \mathrm{L}$, $1.5 \mathrm{mg} / \mathrm{mL}$ アミログルコシターゼ溶液 (Aspergillus niger, 30-60 units/mg protein, A-7420, Sigma) を $1 \mathrm{~mL}$, イソ プロパノールを $100 \mu \mathrm{L}, 37^{\circ} \mathrm{C}$ に加温した蒸留水 $5 \mathrm{~mL}$ を加 え，攪拌後恒温振とう機を用いて $40^{\circ} \mathrm{C}, 60 \mathrm{rpm}$ の振とう 速度で 16 時間振とうした。 反応液に $60^{\circ} \mathrm{C}$ に加温した $95 \%$ エタノール溶液 $200 \mathrm{~mL}$ を添加した後に室温にて 1 時間放 冷した。 ガラスろ過器 (2G2, 東京硝子器械(株))にて濾過 した後に，万過液 $5 \mathrm{~mL}$ を試験管にとり， $4^{\circ} \mathrm{C}, 3000 \mathrm{rpm}$ の条件で 10 分間遠心分離した。 上清に含まれるグルコー ス量を GOD 法 ${ }^{17)}$ を用いて定量した（グルコースாテスト ワコー, 和光純薬工業(株)).

炊飯米の消化性は以下の計算式により算出した。

$$
\begin{array}{r}
\text { 炊飯米の消化率 }(\%)=(\text { 遊離グルコース量g) } \\
\times 100 /(\text { 炊飯前の精白米の風乾重量g) }
\end{array}
$$

消化性試験の結果は 3 点の平均値土標準偏差で示した.

\section{4. 搗精割合（歩留）の異なるあゆのひかりの炊飯米の 消化性試験}

歩留まり $92 \%$ のコシヒカリの精白米と, あゆのひかり については，玄米と歩留まり $93 \% ， 90 \% ， 82 \% ， 65 \%$ およ び $40 \%$ の精白米を用いた，その後，前述の炊飯米の消化性 試験を行った。

\section{5. 搗精割合 (歩留) の異なるあゆのひかりの表層糠の 除去程度の判定}

あゆのひかりの搗精割合の異なる精白米の表層糠の除去

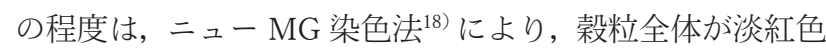
に染色されたとき表層糠が除去されたと判定した。

\section{6. 搗精割合 (歩留) の異なるあゆのひかりの成分分析}

歩留まり $92 \%$ のコシヒカリと歩留まりがいずれも $91 \%$ の夢十色, ミルキークイーンの精白米, およびあゆのひか りについては「4. 搗精割合 (歩留) の異なるあゆのひかり の炊飯米の消化性試験」で用いた各種歩留まりの米試料を 用い, (財) 日本食品分析センターにて米試料に含まれる澱

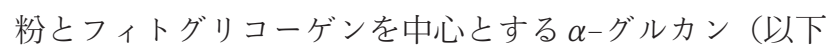
$\alpha$-グルカンと表記), タンパク質, 脂質, ショ糖, 水分, 食 物繊維および扊分のそれぞれの含有率（重量％）を分析し た.

\section{7. あゆのひかりの米断面のヨウ素染色 ${ }^{19)}$}

玄米コシヒカリと玄米あゆのひかりの断面切片を作成し た. 各断面切片を $0.2 \%$ ヨ素 $-2 \%$ ヨウ化カリウム溶液 に浸漬した後に水洗し, マイクロスコープ（VH-5000, 
(株)キーエンス) にて澱粉の所在を検討した.

\section{8. あゆのひかりの炊飯粒の粉砕後の消化性試験}

遠沈管 $(50 \mathrm{~mL})$ に歩留まり $82 \%$ のあゆのひかりの精白 米 $1 \mathrm{~g}$ と, 加水量は後の粉砕操作を考慮して試料の 15 倍 のイオン交換水 $15 \mathrm{~mL}$ を加え，オートクレーブにて $120^{\circ} \mathrm{C}$ で 10 分間加圧加熱処理した後，室温にて 1 時間放冷し，デ ジタルホモジナイザー (HOM, アズワン(株)）にて炊飯粒 を粉砕した. その後, 前述の炊飯米の消化性試験を行った。 対照として未粉砕の炊飯粒を評価した。

\section{9. あゆのひかりの精白米粉砕物の炊飯後の粒度別消化 性試験}

歩留まり $81 \%$ のあゆのひかりの精白米を粉砕機（ST-1, 大阪ケミカル(株)）を用いて粉砕した。目開き $1.400 \mathrm{~mm}$, $0.850 \mathrm{~mm}, 0.600 \mathrm{~mm}$ および $0.355 \mathrm{~mm}$ のステンレス製網ふ るい（TESTING SIEVE 試験用ふるい，東京スクリーン (株)）を用いて，粉砕物を $1.400 \mathrm{~mm}$ の目開きのふるいに 残る (以下 on と表記), $0.850 \mathrm{~mm}$ on $1.400 \mathrm{~mm}$ の目開き のふるいを通過する (以下 pass と表記)， $0.600 \mathrm{~mm}$ on〜 $0.850 \mathrm{~mm}$ pass, $0.355 \mathrm{~mm}$ on〜 $0.600 \mathrm{~mm}$ pass および 0.355 mm pass の 5 段階に分級した。遠沈管 $(50 \mathrm{~mL})$ に各分級 サンプル $1 \mathrm{~g}$ と分級サンプルを十分糊化させるためにイオ ン交換水 $15 \mathrm{~mL}$ を加え，オートクレーブにて $120^{\circ} \mathrm{C} て ゙ ~ 10$ 分間加圧加熱処理を行い，室温にて 1 時間放冷した後，前 述と同様の消化性試験を行った.

\section{0. あゆのひかりの炊飯粒の細胞壁分解酵素処理後の 消化性試験}

歩留まり $90 \%$ のコシヒカリと歩留まり $83 \%$ のあゆのひ かりの精白米を試料に用いた。遠沈管 $(50 \mathrm{~mL})$ に試験米 1 $\mathrm{g}$ およびセルラーゼ処理で酵素を十分に米粒内に浸透する ためイオン交換水 $15 \mathrm{~mL}$ を加え，オートクレーブにて $120^{\circ} \mathrm{C}$ で 10 分間加圧加熱処理した後, 室温にて炊飯粒を 1 時間放冷し，セルラーゼ (Trichoderma reesei, 1640 units / $\mathrm{g}$ ，セルクラスト $1.5 \mathrm{LFG}$, Novozymes） $100 \mathrm{mg}$ を $0.5 \mathrm{M}$ 䣷 酸緩衝液（pH4.8）にて $10 \mathrm{~mL}$ に溶解した細胞壁分解酵素

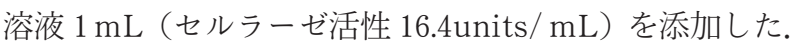
恒温槽にて $40^{\circ} \mathrm{C}, 60 \mathrm{rpm}$ の振とう速度で 24 時間振とう攪 找後，前述の消化性試験を行った。

\section{実験結果および考察}

\section{1. 炊飯米の消化性と米の胚乳澱粉特性との関係}

炊飯米の消化性之米の肧乳澱粉特性之の関係について は，これまでいくつか報告されている. 柳原ら 7 は, 北海道 産米の機能性についての検討の中で，米のアミロース含量 と難消化性澱粉含量との間には密接な関係が認められ，高 アミロース米は特異的に多くの難消化性澱粉を含むことを 報告している。 また酒造好適米の検討で, アミロース含量 が高い米や, アミロペクチンの短鎖/長鎖比の低い米は消 化性が低くなることが報告されている ${ }^{20) ~ 24) . す な わ ち ア ~}$

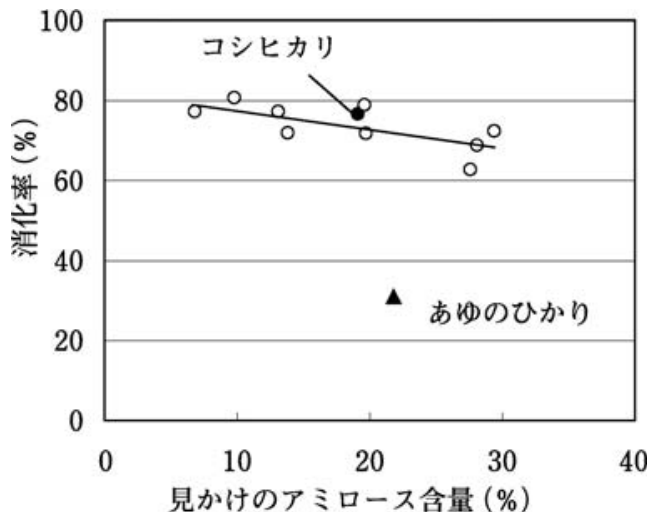

図 1 胚乳澱粉の見かけのアミロース含量と炊飯米の消化率 の関係

回帰直線はあゆのひかりのデー夕を除いて作成した

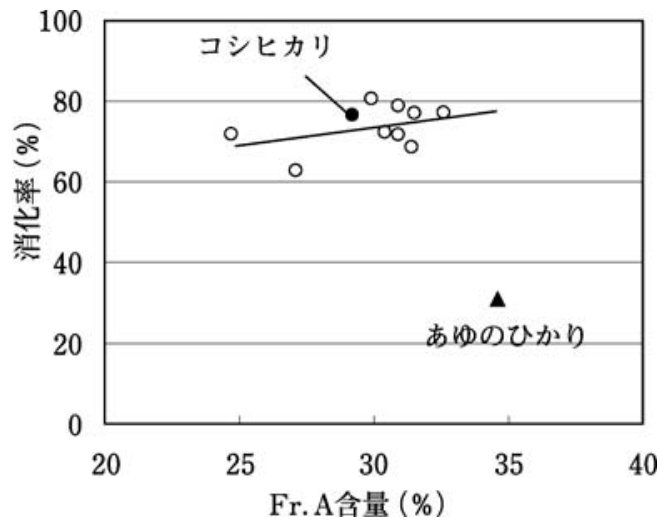

図 2 胚乳澱粉の Fr. A 含量と炊飯米の消化率の関係

回帰直線はあゆのひかりのデータを除いて作成した。

ミロース含量が高い米やアミロペクチンの短鎖/長鎖比の 低い米は老化しやすく，消化性が低いことが報告されてい る.

著者らの結果においても，高アミロース米（肧乳澱粉の 見かけのアミロース含量が $25.0 \%$ 以上）やFr. A 含量が $25 \%$ 程度のアミロペクチンの短鎖/長鎖比の低い米は，良 食味米の代表であるコシヒカリ（胚乳澱粉の見かけのアミ ロース含量 : $19.1 \%$, Fr. A 含量 : $29.2 \%$, 炊飯米の消化率 : $76.6 \pm 1.9 \%$ ）に対して炊飯米の消化率が低い值を示し，お おむね既報の結果と同様の傾向を示した（図 1，図 2)。し かしあゆのひかりの肧乳澱粉は，見かけのアミロース含量 が $21.8 \%$, Fr. A 含量は 34.6\% となり，中アミロース米で かつ Fr. A 含量がコシヒカリより高いにも関わらず，炊飯 米の消化率が $31.3 \pm 3.5 \%$ となり，11 品種の中で最も低い 值を示した。すなわちあゆのひかりは見かけのアミロース 含量やアミロペクチン側鎖長分布等の胚乳澱粉の構造特性 から炊飯米の低い消化率を説明することは難しかったこと から，他の要因で炊飯米の消化率が低下していると考えら れた。そこであゆのひかりの炊飯米の消化率が低くなる要 
因について検討した。

\section{2. 表層糠と $\alpha$-グルカン含量の影響}

あゆのひかりの穀粒（図 3）は，粒厚が薄く㱀が多い特 徵 ${ }^{10)}$ をむので, 通常の歩留まり $90 \%$ の搗精では糠が完 全に除去できず消化率低下の原因となる可能性も考えられ た。そこでニューMG 染色法により表層の糠が無くなるま で搗精した精白米試料を用いて，炊飯米の消化性試験を 行った。 また基本成分（ $\alpha$-グルカン, タンパク質, 脂質, ショ糖，水分，食物繊維および死分）を分析した。図 4 に 示すようにあゆのひかりの玄米試料を用いた炊飯米の消化 率は $10.1 \pm 0.6 \%$ となり, 試料米を搗精するに従い消化率 がやや上昇したが，表層糠がほぼ無くなる歩留まり $65 \%$ では消化率 $38.9 \pm 1.8 \%$ ，表層糠が無くなる歩留まり $40 \%$ においてあ消化率 $56.4 \pm 1.1 \%$ となり，歩留まり $92 \%$ コシ

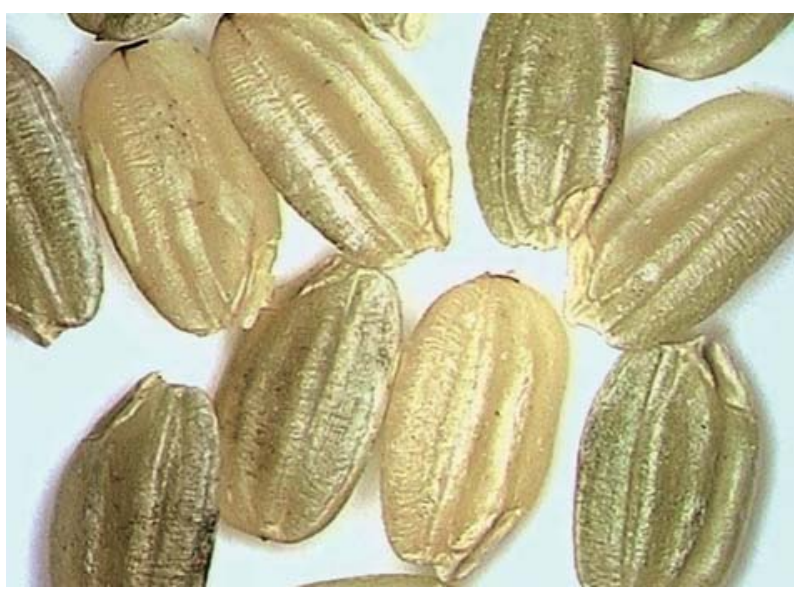

図 3 あゆのひかり玄米の外観
ヒカリの消化率 $76.6 \pm 1.9 \%$ より低い值であった，成分分 析結果（図 5) に拈いて，コシヒカリ，夢十色，ミルキーク

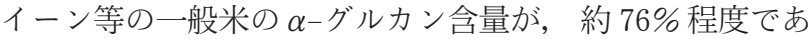
るのに対し，あゆのひかりの玄米，歩留まり $93 \% ， 82 \%$ の 精白米試料ではそれぞれ $61.4 \% ， 64.5 \% ， 69.1 \%$ であった.

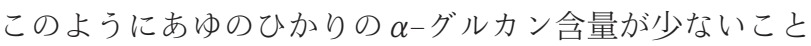
がこれらの消化率低下の一要因であると考えられた。しか し表層糠がほぼ無くなる歩留まり $65 \%$ や表層糠が無くな

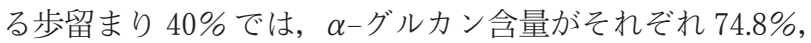
$78.7 \%$ となり，コシヒカリ等の一般米とほぼ同等であるに あかかわらず消化率が低かった。すなわちあゆのひかりの 炊飯米の消化率低下には，あゆのひかりの表層糠や $\alpha-ク ゙$

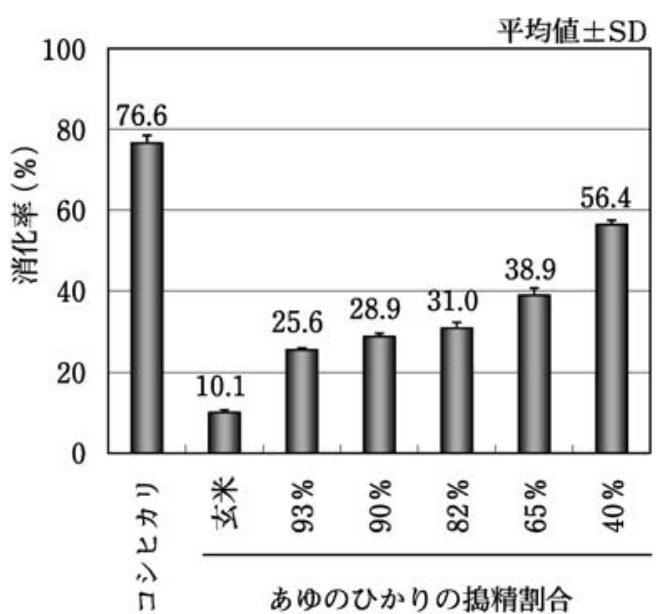

図 4 玄米および搗精割合（歩留）の異なるあゆのひかりの 試料米および $92 \%$ 歩留のコシヒカリを試験米に用い た炊飯米の消化率

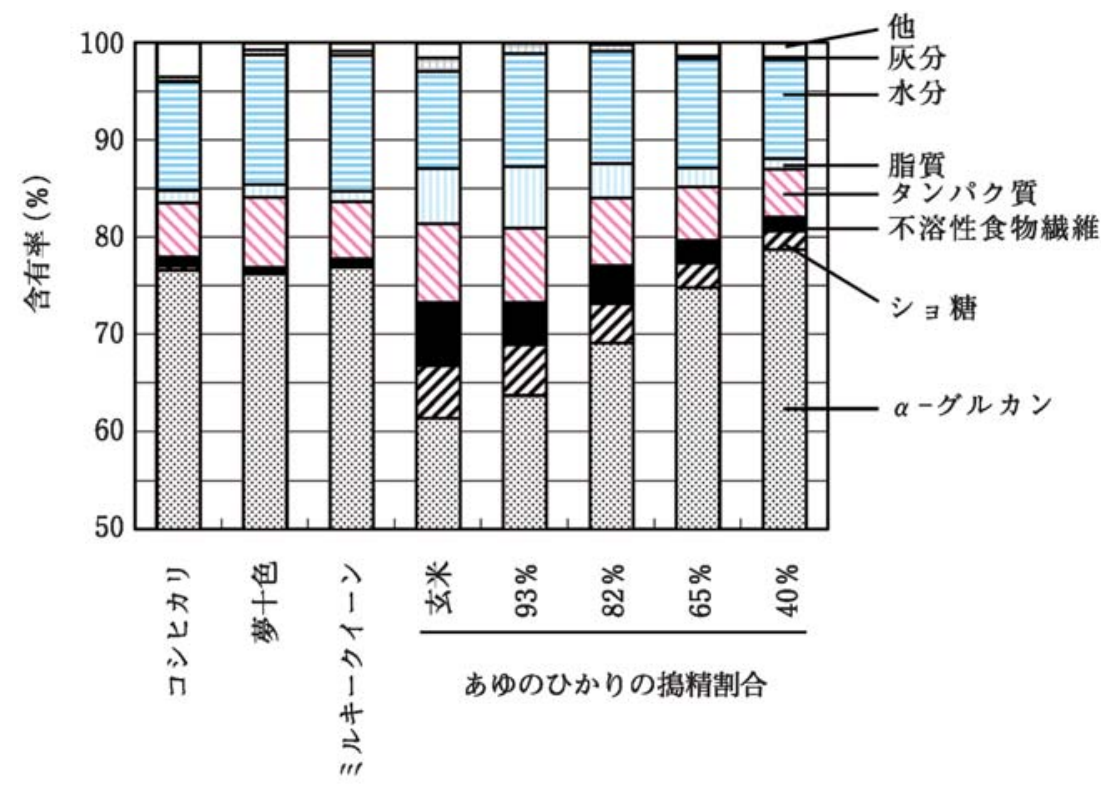

図 5 玄米および搗精割合（歩留）の異なるあゆのひかりの試料米および約 $90 \%$ 歩留の他品種精白米の成分割合 
ルカン含量以外の要因が存在することが示唆された.

\section{3. フィトグリコーゲンの影響}

あゆのひかりの炊飯米の消化率が低い二つ目の要因とし て考えたのがあゆのひかりの精白米に含まれているフィト グリコーゲンである. あゆのひかりの精白米粉末固形分に 含まれるフィトグリコーゲン含量は $9.8 \%$ であり ${ }^{25)}$, コシ ヒカリに比べて，フィトグリコーゲン含量が高い（表 1). あゆのひかりの米粒内に拈けるフィトグリコーゲンの所在 を検討するために，玄米断面切片のヨウ素染色を行い， マ イクロスコープによる観察を行った（図 6).Kubo ら ${ }^{26)} に$ よると，あゆのひかりの親である EM5（糖質米）をヨウ素 染色した結果, 澱粉は米粒表面側に，フィトグリコーゲン は米粒の中心に存在することを報告している．著者らの検 討においてああゆのひかりの米粒中心は染色されず，フィ トグリコーゲンは米粒の中心部に多く存在することを確認 した。すなわちあゆのひかりの搗精割合を高めると，米粒 表層に多く存在する澱粉が除去されて, フィトグリコーゲ ン含量が高まることが予想された。しかし前述の搗精割合 別の消化率では，搗精割合が高まるとともに消化率は上昇 した (図 4).これらの結果から，フィトグリコーゲンはあ ゆのひかりの消化抑制効果の要因としての可能性は低いと 考えられた。 また，フィトグリコーゲンの炊飯米食味への 影響を検討する目的で，澱粉とフィトグリコーゲン以外の 成分含量が類似している歩留まり $90 \%$ コシヒカリと歩留 まり 40\%あゆのひかりの炊飯米について「粘り」の食味官 能評価を行った結果，あゆのひかりでは「粘り」が弱かっ た.この結果より，フィトグリコーゲンは，炊飯米物性の 「粘り」を弱くする性質を示すことが考えられた。

表 1 あゆのひかりとコシヒカリの精白米粉末固形物中の 成分割合 ${ }^{25)}$

\begin{tabular}{lccc}
\hline \hline & 澱粉 & 水溶性多糖 & 可溶性低分子糖 \\
\hline コシヒカリ & $92.6 \%$ & $0.5 \%$ & $0.6 \%$ \\
あゆのひかり & $73.1 \%$ & $9.8 \%$ & $8.0 \%$ \\
\hline
\end{tabular}

\section{4. 難消化性構造の可能性}

試料に用いた 11 品種の炊飯米の消化性試験後の残渣形 状を観察した。 あゆのひかり以外の米試料は，図 7 に示す コシヒカリのように筋状もしくは䋊維状となり米粒の原形 を保持していないのに対し，あゆのひかりは搗精割合の違 いにかかわらず消化残渣がほぼ消化性試験前の米粒の原形 を保持していた，著者らはこの現象に着目し，難消化性構 造の可能性について検討した。すなわち歩留まり $82 \%$ の あゆのひかりの炊飯米をホモジナイザーで粉砕した後に消 化性試験を行った．未粉砕では消化率が $38.0 \pm 1.3 \%$ で あったのに対し，粉砕した試料の消化率は $69.6 \pm 3.3 \%$ ま で上昇した（図 8)。この結果から，あゆのひかりの炊飯米 には難消化性構造が存在していると考えられた。

一般に米の胚乳部の断面を観察すると, 約 $40 \times 50$ ～ $80 \times$ $105 \mu \mathrm{m}^{2}$ の大きさの胚乳細胞が重なっており，この細胞の 中に澱粉粒や顆粒状タンパク質が充満している ${ }^{27)}$ 。また肧 乳細胞壁はセルロースミクロフィブリルとその間を埋める マトリックス成分からなっていることが知られている ${ }^{28)}$. 吉沢ら ${ }^{29)}$ は酒造用原料米の消化性に関する研究において, 蒸米のアミラーゼ消化性の品種間差が, 米粒の肧乳細胞が 砕かれている 100 メッシュ篩を通過するまで粉砕すると無

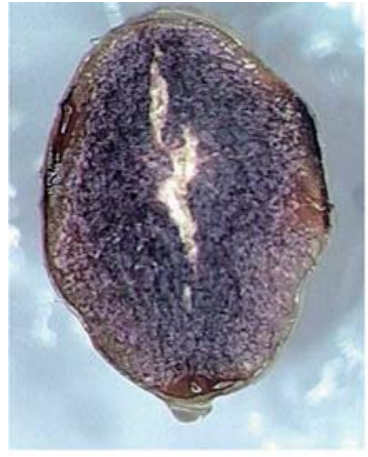

コシヒカリ

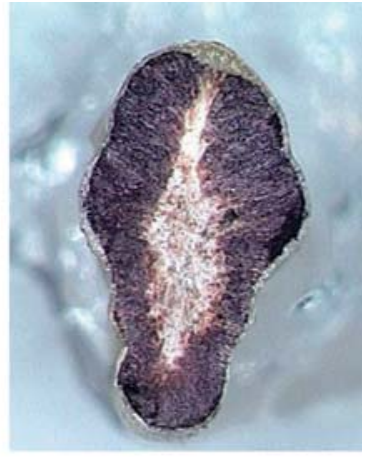

あゆのひかり
図 6 ヨウ素染色した米粒断面

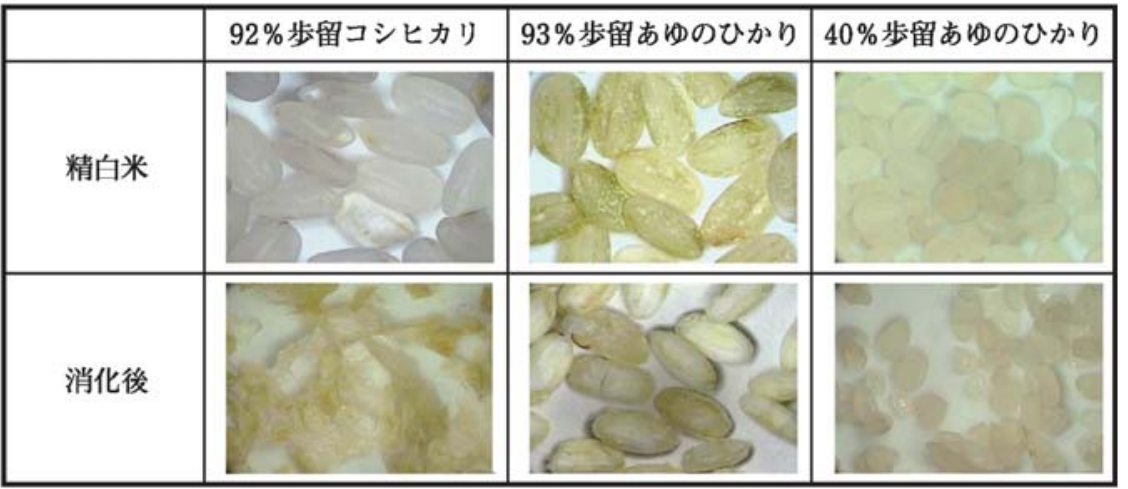

図 7 92\% 歩留コシヒカリおよび搗精割合（歩留）の異なるあゆのひかり精白米と これらを試料米に用いた炊飯米の消化試験後の米粒形状 


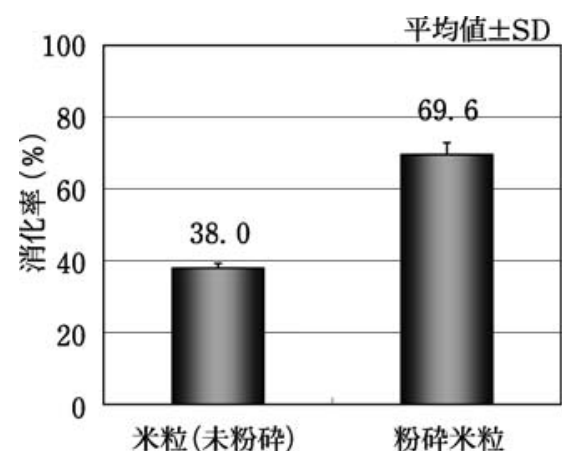

図 $882 \%$ 歩留あゆのひかりの精白米を試料に用いた炊飯米 の米粒 (未粉砕) とその粉砕米粒の消化率

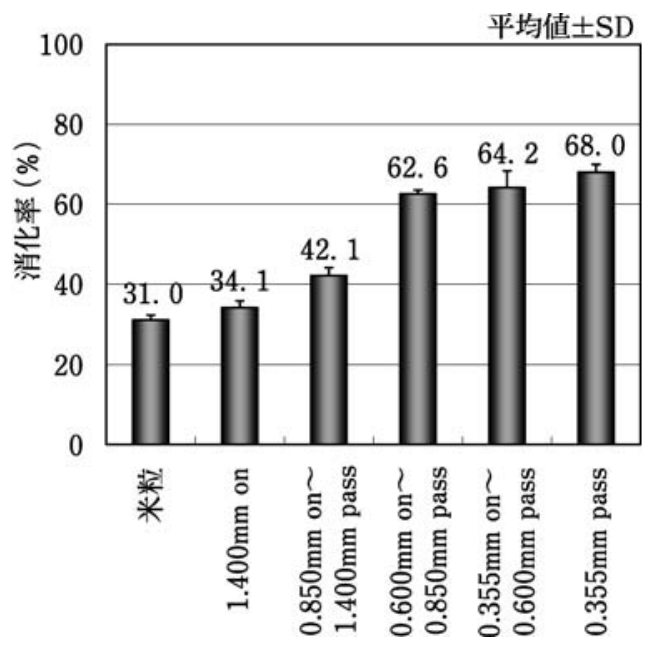

図 $981 \%$ 歩留あゆのひかりの精白米の米粒および粒度の異 なる粉砕米粒を試料に用いた炊飯米の消化率

くなることから，米粒の消化性には胚乳細胞が大きく関与 していると報告している。さらに彼らは肧乳細胞壁に一部 損傷を与えて酵素を通過し易くすると米粒の消化性が上昇 することが推定できると考察している，著者らむ同様に肧 乳細胞壁による難消化作用の可能性を検討する目的で, 歩 留まり $81 \%$ のあゆのひかりの精白米を粉砕し, 粒度別の 消化性試験を行った，米粒での消化率が $31.0 \pm 1.2 \%$ に対 し, 粒度が細かくなるに従い消化率が上昇し, 粒度 0.600 $\mathrm{mm}$ on $\sim 0.850 \mathrm{~mm}$ pass, $0.355 \mathrm{~mm}$ on $\sim 0.600 \mathrm{~mm}$ pass, $0.355 \mathrm{~mm}$ pass では，消化率がそれぞれ $62.6 \pm 1.0 \%, 64.2$ $\pm 4.2 \% ， 68.0 \pm 2.0 \%$ となり，0.850 mm 以下の粒度では消 化率がほぼ一定であった (図 9). すなわち肧乳細胞壁に損 傷を与えると消化抑制効果が見られなくなった。

また三上ら ${ }^{30) 31)}$ は蒸米の溶解・糖化に関する研究におい て, 胚乳細胞壁はアミラーゼ系酵素の作用を受けにくい形 態で存在しており, セルロース，ヘミセルロース，ペクチ ン質分解酵素等の細胞壁分解酵素を用いて蒸米の胚乳細胞 壁を分解すると, 蒸米溶解が促進されることが期待できる ことを報告している．著者らは歩留まり $90 \%$ のコシカ リと歩留まり $83 \%$ のあゆのひかりの炊飯粒をセルラーゼ

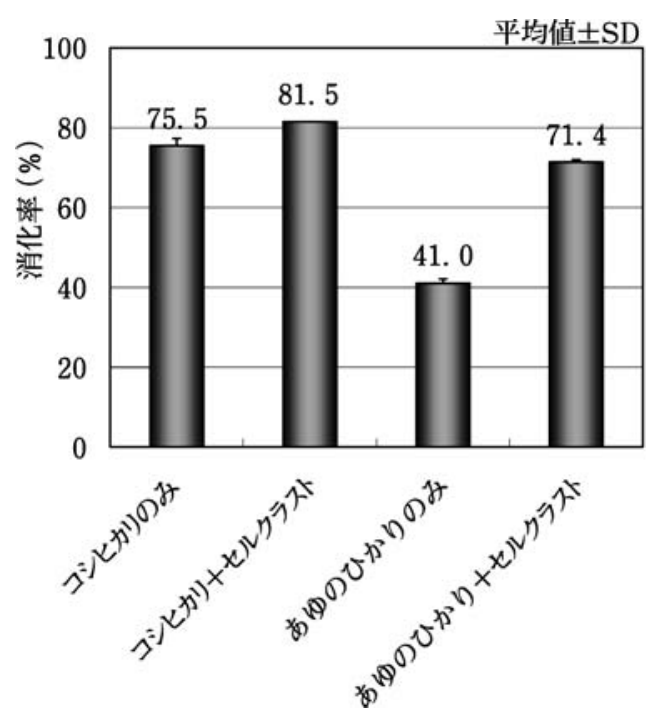

図 $1090 \%$ 歩留コシヒカリおよび $83 \%$ 歩留あゆのひかりの 精白米の試料を用いた炊飯米に対し, セルラーゼ処 理を施した場合と末処理の場合の消化率

処理した後に消化性試験を行った。セルラーゼ処理によ り，コシヒカリでは，75.5土1.8\%から $81.5 \pm 0.01 \%$ と若干 の消化率上昇に留まったのに対し, あゆのひかりでは, $41.0 \pm 1.1 \%$ から $71.4 \pm 0.6 \%$ と大きく消化率が上昇した (図 10). またセルラーゼ処理したあゆのひかりの消化後の 残渣形状は, 筋状となり米粒の崩壊を確認した。 また, 図 5 に示した成分結果より，コシヒカリ等一般の米の不溶性 食物繊維含量は $0.5 \sim 0.9 \%$ であるのに対し， あゆのひかり の歩留まり $65 \% ， 40 \%$ においては，それぞれ $2.3 \% ， 1.5 \%$ 含有する結果を得ており, 量的な面において屯肧乳細胞壁 含量が多いことが示唆された。以上の結果よりあゆのひか りは, 難消化性構造を有し, その構造は肧乳細胞壁が強固 であることが示唆された。これらのことから，あゆのひか りの炊飯米が高い消化抑制効果を示すと考えられた。

要約

国内で栽培された 11 品種の精白米を対象に, in vitroの 炊飯米消化性試験および肧乳澱粉の構造特性試験を行っ た. in vitro 消化性試験は，炊飯米を消化酵素で処理した 後に遊離するグルコース量を分析することで試験した．胚 乳澱粉の構造特性は，見かけのアミロース含量とFr. A 含 量（DP6-12）の試験により評価した。糖質米であるあゆの ひかりは，低・中・高アミロース種を含む 11 品種の試験 米の中で最も消化率が低かった。 あゆのひかりの肧乳澱粉 の見かけのアミロース含量および Fr. A 含量 (DP6-12) は，それぞれ $21.8 \% ， 34.6 \%$ であた。 あゆのひかりの炊 飯米の消化抑制効果の要因を胚乳澱粉の構造特性から説明 することは難しかった。さらにあゆのひかりの特徽として は, 炊飯米での消化性試験後にも米粒の原形を保持するこ とを見出した。この消化抑制効果は粉砕した試料を用いる 
と無くなることから, あゆのひかりは難消化性構造を持つ と考えられた。また，この難消化性構造には肧乳細胞壁が 関与していることが示唆された。

最後に貴重な試料をいただいた，(独)農業・食品産業技 術総合研究機構北陸研究センター三浦清之先生に深く感謝 致します.

\section{文献}

1）厚生労働省，平成 18 年国民健康・栄養調査結果の概要, 2008 年 4 月 30 日.

2）伊勢一男, 赤間芳洋, 堀末 登, 中根 晃, 横尾政雄, 安東 郁男, 羽田丈夫, 須藤 充, 沼口賢治, 根本 博, 古舘 宏, 井辺時雄, 低アミロース良食味水稲品種「ミルキークイー ン」の育成，作物研究所研究報告， 2，39-61（2001）.

3）上原泰樹，小林 陽，古賀義昭，内山田博士，清水博之，太 田久稔，福井清美，大槻 寛，三浦清之，堀内久満，奥野員 敏, 藤田米一, 石坂昇助, 中川原捷洋, 山田利昭, 水稲新品 種「夢十色」の育成，北陸農業試験場報告，39，23-47 (1997).

4）佐藤 光, イネ胚乳澱粉変異体の作製とその解析, 農化, 68, 1577-1580 (1994).

5) Inouchi, N., Study on structures and physical properties of endosperm starches of rice and other cereals. J. Appl. Glycosci., 57, 13-23 (2010).

6) Horibata,T.,Nakamoto, M., Fuwa, H. and Inouchi, N., Structural and physicochemical characteristics of endosperm starches of rice cultivars recently bred in Japan. J. Appl. Glycosci., 51, 303-313 (2004).

7）柳原哲司, 中森朋子, 加藤 淳, 難消化性成分からみた北海 道米の機能性解析, 平成 14 年度 新しい研究成果一北海道 地域一，148-151（2004）。

8) James, M.G., Robertson, D.S. and Myers, A.M., Characterization of the maize gene sugaryl, a determinant of starch composition in kernels. Plant Cell, 7, 417-429 (1995)

9）東 正昭, 斉藤 滋, 池田良一, 春原嘉弘, 松本定夫, 井上 正勝，小山田善三，山口誠之，小綿寿志，横尾政雄，超多収 水稲品種「ふくひびき」の育成, 東北農業試験場研究報告, 88, 15-38 (1994).

10）三浦清之，上原泰樹，小林 陽，太田久稔，清水博之，笹原 英樹, 福井清美, 小牧有三, 後藤明俊, 重宗明子, 大槻 寛, 水稲新品種「あゆのひかり」の育成, 中央農業総合研究セン 夕一研究報告，9，1-16（2007）。

11）山本和夫, 沢田澄恵, 小野垣俊雄, アルカリ法による米澱粉 の調製とその性状について, 澱粉科学，20，99-104 (1973).

12) Ikawa, Y., Glover, D.V., Sugimoto, Y. and Fuwa, H., Some structural characteristics of starches of maize having a specific genetic background. Starch/Stärke, 33, 9-13 (1981).

13) Takami, K., Nakaura, Y., Horibata, T., Koriyama, T. and Inouchi, N., Relationship between physical properties of cooked rice and properties of endosperm starches of new types of rice grains. J. Appl. Glycosci., 51, 355-362 (2004).

14) Koizumi, K., Fukuda, M. and Hizukuri, S., Estimation of the distributions of chain length of amylopectins by high-performance liquid chromatography with pulsed amperometric detection. J. Chromatogr., 585, 233-238 (1991).

15) Inouchi, N., Nishi, K., Tanaka, S., Asai, M., Kawase, Y., Hata, Y., Konishi, Y., Yue, S. and Fuwa, H., Characterization of amaranth and quinoa starches. J. Appl. Glycosci., 46, 233-240 (1999).

16) Åkerberg, A.K.E., Liljeberg, H.G.M., Granfeldt, Y.E., Drews, A.W. and Björck, I.M.E., An in vitro method, based on chewing, to predict resistant starch content in foods allows parallel determination of potentially available starch and dietary fiber. J. Nutr., 128, 651-660 (1998).

17) Miwa, I., Okuda, J., Maeda, K. and Okuda, G., Mutarotase effect on colorimetric determination of blood glucose with $\beta$-D-glucose oxidase. Clin. Chim. Acta., 37, 538-540 (1972).

18）大坪研一，米の美味しさに関係する諸特性の測定法，「美味 しい米 第 2 巻 米の美味しさの科学」，（社団法人農林水 産技術情報協会，東京), pp. 92-93 (平成 8 年).

19）佐々木堯，植物試料中の測粉の定性および定量，「測粉・関 連糖質実験法」, 初版 ((株)学会出版センター, 東京), pp 1-8 (1986).

20）荒巻 功，吉井美華，岩瀬新吾，江辺正英，菅野喜浩，菊永 雪絵, 奥田将生, 小関卓也, 橋爪克己, 酒造原料米のアミロ ペクチン側鎖構造と酒造適性，酫協，99，457-466（2004）.

21）小関卓也，奥田将生，米原由希，八田一隆，岩田 博，荒巻 功，橋爪克己，イネ登熟期の高温が酒造適性に及ぼす影響, 醇協，99，591-596（2004）.

22）米原由希，小関卓也，奥田将生，荒巻 功，橋爪克己，イネ 登熟期の低温が酒造適性に及ぼす影響, 醸協, 100，650-657 (2005).

23) Okuda, M., Aramaki, I., Koseki, T., Inouchi, N. and Hashizume,K., Structural and retrogradation properties of rice endosperm starch affect enzyme digestibility of steamed milled-rice grains used in sake production. Cereal Chem., 83, 143-151 (2006).

24) Okuda, M., Aramaki, I., Koseki, T., Satoh, H. and Hashizume, K., Structural characteristics, properties, and in vitro digestibility of rice. Cereal Chem., 82, 361-368 (2005).

25）井ノ内直良, 糖質米の肧乳澱粉と水溶性多糖に関する研究, 飯島記念食品科学振興財団年報, 2000， 116-121（2002）.

26) Kubo, A., Fujita, N., Harada, K., Matsuda, T., Satoh, H. and Nakamura, Y., The starch-debranching enzymes isoamylase and pullulanase are both involved in amylopectin biosynthesis in rice endosperm. Plant Physiol. 121, 399-409 (1999).

27）竹生新治郎, 米の食味,「米の科学」, 初版（(株)朝倉書店, 東京), pp. 117-125 (1995).

28）渋谷直人，米の細胞壁の化学構造と品質，日食工誌， 37 740-748 (1990)

29）吉沢 淑, 百瀬洋夫, 石川雄章, 米粒の構造と消化に関する 研究（第 8 報）米粒及び米粉の消化性，醸協，74，190-193 (1979).

30）三上重明，清酒醉造における細胞壁分解酵素の機能，醸協, 102, 46-47 (2007)

31）山根雄一，福田 央，三上重明，木崎康造，若林三郎，黄敖 菌 Aspergillus oryzae が生産するセルラーゼの性質とその 清酒屯ろみ醸造への効果，醸協，99，84-92（2004）。

(平成 22 年 2 月 12 日受付，平成 22 年 6 月 15 日受理) 